\title{
Warty-Basaloid Carcinoma of the Penis
}

National Cancer Institute

\section{Source}

National Cancer Institute. Warty-Basaloid Carcinoma of the Penis. NCI Thesaurus. Code C159250.

A squamous cell carcinoma that arises from the penis. It is characterized by a warty (condylomatous) and basaloid features. 